DOI 10.22460/jpmi.v1i3.347-354

\title{
KEMAMPUAN PENALARAN MATEMATIK SISWA MTs
}

\author{
Mochamad Try Suharto ${ }^{1}$, Siti Chotimah ${ }^{2}$ \\ ${ }^{1,2}$ IKIP Siliwangi, Jl. Terusan Jenderal Sudirman, Cimahi, Jawa Barat, Indonesia \\ ${ }^{1}$ m3suharto@yahoo.co.id, ${ }^{2}$ chotimah019@gmail.com
}

Diterima: 14 April 2018; Disetujui: 28 Mei 2018

\begin{abstract}
Reasoning is the ability to find a way to get the truth. In terminology, logic is the science that governs the process of human thinking so that the results presented can reach the truth. So it can be concluded also that by reasoning, humans can make an argument that is absolute and can be accepted by others through logical thinking. This research was conducted to determine the mathematical reasoning ability of MTs class 8 students (delapan) on Triangle and Quadrilateral material based on indicators of mathematical reasoning ability that is to draw a logical conclusion and compose an argument, analogical reasoning, transductive reasoning, deductive reasoning, generalization and estimate answers, solutions or tendency with non-routine troubleshooting. The research method used is descriptive qualitative with data to be analyzed is qualitative data in the form of written and oral answers obtained from written test . This research was conducted in MTs PPI 38 Padalarang with the subject of this research is class VIII-A which amounted to 31 people. Based on the results of research, students' mathematical reasoning abilities on MTs PPI 38 Padalarang are classified as sufficient. This is because there are some reasoning indicators that still need to be improved especially on analytical reasoning and generalization indicator as stated in table which have been described.
\end{abstract}

Keywords: Mathematical Reasoning, Triangle and Quadrilateral

\begin{abstract}
Abstrak
Menalar adalah kemampuan dalam menemukan suatu cara untuk mendapatkan kebenaran. Secara istilah, logika adalah ilmu pengetahuan yang mengatur proses berpikir manusia sehingga hasil yang dikemukakan dapat mencapai kebenaran. Sehingga dapat disimpulkan pula bahwa dengan bernalar, manusia dapat membuat suatu argumen yang sifatnya mutlak dan dapat diterima oleh orang lain melalui pemikirannya yang logis. Penelitian ini dilakukan untuk mengetahui kemampuan penalaran matematik siswa MTs kelas 8 (delapan) pada materi Segitiga dan Segiempat berdasarkan indikator kemampuan penalaran matematik yaitu menarik kesimpulan logis dan menyusun suatu argumen, penalaran analogi, penalaran transduktif, penalaran deduktif, generalisasi dan memperkirakan jawaban, solusi atau kecenderungan dengan pemecahan masalah tidak rutin. Metode penelitian yang digunakan adalah deskriptif kualitatif dengan data yang akan dianalisis adalah data kualitatif dalam bentuk jawaban tertulis dan lisan yang diperoleh dari tes tertulis. Penelitian ini dilakukan di MTs PPI 38 Padalarang dengan subjek penelitian ini adalah kelas VIII-A yang berjumlah 31 orang). Berdasarkan hasil penelitian, kemampuan penalaran matematik siswa pada MTs PPI 38 Padalarang digolongkan dengan kategori cukup. Hal ini dikarenakan adanya beberapa indikator penalaran yang masih perlu ditingkatkan terutama pada indikator penalaran analogi dan generalisasi sebagaimana yang tertera pada tabel yang sudah diuraikan.
\end{abstract}

Kata Kunci: Penalaran Matematik, Segitiga dan Segiempat

How to cite: Suharto, M. T., \& Chotimah, S. (2018). Kemampuan Penalaran Matematik Siswa MTs. JPMI - Jurnal Pembelajaran Matematika Inovatif, 1 (3), 347-354. 


\section{PENDAHULUAN}

Menalar adalah kemampuan dalam menemukan suatu cara untuk mendapatkan kebenaran. Secara istilah, logika adalah ilmu pengetahuan yang mengatur proses berpikir manusia sehingga hasil yang dikemukakan dapat mencapai kebenaran. Sehingga dapat disimpulkan pula bahwa dengan bernalar, manusia dapat membuat suatu argumen yang sifatnya mutlak dan dapat diterima oleh orang lain melalui pemikirannya yang logis (Hermawan \& Hidayat, 2018; Hidayat, 2017; Hidayat \& Prabawanto; 2018; Sholihat, Hidayat, \& Rohaeti, 2018; Sumarmo, Hidayat, Zukarnaen, Hamidah, \& Sariningsih, 2012).

Dalam bidang pendidikan, kemampuan menalar merupakan tujuan pembelajaran. Hal ini didasarkan pada Depdiknas bahwa tujuan dari pembelajaran adalah: a)Melatih cara berpikir dan bernalar dalam menarik kesimpulan, b)Mengembangkan aktifitas kreatif yang melibatkan imajinasi, intuisi dan penemuan dengan mengembangkan pemikiran yang divergen, orisinil, rasa ingin tahu, membuat prediksi dan dugaan serta mencoba - coba, c)Mengembangkan kemampuan penyampaian informasi atau mengkomunikasikan gagasan (Amelia, 2015). Dengan pembelajaran melalui bernalar, siswa dapat menemukan informasi melalui argumen yang didapatnya dan bertukar informasi dengan orang lain sehingga dapat mengembangkan sikap rasa ingin tahu, mau menerima kritik dan saran dari orang lain dan percaya diri akan kemampuan dirinya sendiri.

Sumarmo menyatakan bahwa penalaran matematik terdiri atas penalaran induktif dan deduktif. Pada penalaran induktif terdapat enam indikator yaitu: a)Penalaran transduktif, b)Penalaran analogi, c)Penalaran generalisasi, d)Memperkirakan jawaban, solusi atau kecenderungan, interpolasi dan ekstrapolasi, e)Memberi penjelasan terhadap model, fakta, sifat, hubungan atau pola yang ada, f)Menggunakan pola hubungan untuk menganalisis situasi dan menyusun konjektur. Pada penalaran deduktif terdapat tiga indikator yaitu: a)Melaksanakan perhitungan berdasarkan aturan atau rumus yang berlaku, b)Menarik kesimpulan logis yang terdiri atas penalaran proporsional, proposisional, memeriksa validitas argumen, membuktikan dan menyusun valid, penalaran probabilitas dan kombinatorial, c)Menyusun pembuktian langsung, pembuktian tak langsung dan pembuktian dengan induksi matematika (Hendriana, Rohaeti, \& Sumarmo, 2017).

Dalam mengerjakan soal tentang penalaran, ditemukan kesulitan - kesulitan yang dialami siswa. Sumarni mengatakan bahwa pada siswa jenjang SMP terdapat kesulitan dalam mengerjakan soal yang berkaitan dengan penalaran matematik terutama indikator generalisasi dengan 40,20 \% dari SMI dan penalaran deduktif dengan $29 \%$ - $41 \%$ dari SMI (Sumarni \& Sumarmo, 2016). Ruslan menyebutkan bahwa siswa kesulitan dalam menyelesaikan soal yang berkaitan dengan indikator menguji suatu argumen karena belum terbiasa dengan menggunakan model saat pembelajaran (Ruslan \& Santoso, 2013). Ario menyebutkan pula bahwa kesulitan siswa yang dialami saat mengerjakan soal yang berkaitan dengan penalaran matematik adalah terletak pada indikator memeriksa validitas argumen, analogi, generalisasi dan mengikuti aturan interferensi (Ario, 2015). Yenni memaparkan sebanyak 66,67 \% dari 33 siswa belum bisa menjawab dengan baik tentang soal yang berkaitan dengan indikator memberi alasan atau bukti terhadap beberapa solusi (Yenni \& Aji, 2016).

Berdasarkan masalah tersebut, peneliti tertarik untuk mengetahui kemampuan penalaran matematik siswa pada jenjang MTs. Penelitian ini dilakukan untuk mengetahui kemampuan penalaran matematik siswa MTs kelas 8 (delapan) pada materi Segitiga dan Segiempat berdasarkan indikator kemampuan penalaran matematik yaitu menarik kesimpulan logis dan menyusun suatu argumen, penalaran analogi, penalaran transduktif, penalaran deduktif, 
generalisasi dan memperkirakan jawaban, solusi atau kecenderungan dengan pemecahan masalah tidak rutin. Dengan penelitian ini diharapkan pendidik dapat melihat gambaran kemampuan penalaran matematik siswa terutama jenjang MTs sehingga terdapat solusi dari hasil yang telah diuraikan.

\section{METODE}

Metode penelitian yang digunakan adalah deskriptif kualitatif dengan data yang akan dianalisis adalah data kualitatif dalam bentuk jawaban tertulis dan lisan yang diperoleh dari tes tertulis. Penelitian ini dilakukan di MTs PPI 38 Padalarang dengan subjek penelitian ini adalah kelas VIII-A yang berjumlah 31 orang yang sudah mempelajari materi Segitiga dan Segiempat di kelas 7 (tujuh).

Pelaksanaan kegiatan penelitian ini telah melalui tahap perizinan kepada pihak sekolah, pemilihan kelas untuk dijadikan subjek penelitian, menyusun dan memberikan instrumen penelitian serta menganalisis jawaban siswa berdasarkan indikator kemampuan penalaran matematik yang ada pada kisi - kisi soal.

Dalam penyusunan instrumen penelitian. Soal - soal tersebut berkaitan dengan materi Segitiga dan Segiempat kemudian hasil jawaban siswa akan dianalisis dengan cara mengklasifikasikan siswa berdasarkan hasil jawaban, mengubahnya menjadi data dan menarik suatu kesimpulan dari hasil data tersebut. Kisi - kisi soal tes kemampuan penalaran matematik siswa disusun seperti berikut:

Tabel 1. Kisi - kisi Soal Tes Penalaran Matematik

\begin{tabular}{llc}
\hline No & \multicolumn{1}{c}{ Indikator Penalaran Matematik } & No. Soal \\
\hline 1 & $\begin{array}{l}\text { Menarik kesimpulan logis dan menyusun } \\
\text { suatu argumen }\end{array}$ & 1 \\
\hline 2 & Penalaran Analogi & 2 \\
\hline 3 & Penalaran Transduktif & 3 \\
\hline 4 & Penalaran Deduktif & 4 dan 5 \\
\hline 5 & Generalisasi & 6 \\
\hline 6 & Pemecahan masalah tidak rutin & 7 dan 8 \\
\hline
\end{tabular}

Untuk rubik penskoran, peneliti menggunakan uraian Thompson sebagai berikut (Sulistiawati, Suryadi, \& Fatimah, 2015) :

Tabel 2. Rubik Penskoran Penalaran Matematik

\begin{tabular}{ll}
\hline Skor & \multicolumn{1}{c}{ Kriteria } \\
\hline 4 & Jawaban secara substansi benar dan lengkap \\
\hline 3 & Jawaban memuat satu kesalahan atau kelalaian yang signifikan \\
\hline 2 & $\begin{array}{l}\text { Sebagian jawaban benar dengan satu atau lebih kesalahan atau } \\
\text { kelalaian yang signifikan }\end{array}$ \\
\hline 1 & $\begin{array}{l}\text { Sebagian besar jawaban tidak lengkap tetapi paling tidak memuat } \\
\text { satu argumen yang benar }\end{array}$ \\
\hline 0 & $\begin{array}{l}\text { Jawaban tidak benar berdasarkan proses atau argumen, atau tidak } \\
\text { ada respon sama sekali }\end{array}$ \\
\hline
\end{tabular}




\section{HASIL DAN PEMBAHASAN}

Kemampuan penalaran matematik siswa ini diimplementasikan dalam bentuk soal yang dimana setiap soalnya mencakup satu indikator penalaran matematik. Pada soal nomor satu yang berkaitan dengan menarik kesimpulan logis dan menyusun suatu argumen, sebanyak 52 $\%$ siswa dapat mengerjakan soal tersebut. $31 \%$ siswa dapat mengerjakan soal nomor dua yang berkaitan dengan penalaran analogi atau menemukan keserupaan konsep, $59 \%$ siswa mampu mengerjakan soal tentang penalaran transduktif atau menarik kesimpulan dari suatu kasus pada kasus yang lainnya, $66 \%$ siswa mampu mengerjakan soal tentang penalaran deduktif atau melaksanakan perhitungan berdasarkan aturan yang berlaku, $49 \%$ siswa mampu mengerjakan soal yang berkaitan dengan penalaran deduktif, $31 \%$ siswa mampu mengerjakan soal tentang generalisasi, $52 \%$ siswa mampu mengerjakan soal tentang pemecahan masalah tidak rutin dan $66 \%$ siswa mampu mengerjakan soal tentang pemecahan masalah tidak rutin. Hasil dari kemampuan penalaran matematik siswa dapat dilihat pada tabel berikut:

Tabel 3. Standar Maksimal Indikator (SMI)

\begin{tabular}{ccccccccc}
\hline Soal & 1 & 2 & 3 & 4 & 5 & 6 & 7 & 8 \\
\hline SMI & 4 & 4 & 4 & 4 & 4 & 4 & 4 & 4 \\
\hline Rata - rata & 2.06452 & 1.25806 & 2.35484 & 2.51613 & 1.96774 & 1.22581 & 2.09677 & 2.64516 \\
\hline Persentase & $52 \%$ & $31 \%$ & $59 \%$ & $66 \%$ & $49 \%$ & $31 \%$ & $52 \%$ & $66 \%$ \\
\hline
\end{tabular}

Untuk indikator pertama yang berkaitan dengan menarik kesimpulan logis dan menyusun suatu argumen, diperoleh hasil jawaban siswa dalam bentuk tabel sbagai berikut:

Tabel 4. Hasil Jawaban Siswa Pada Indikator Pertama

\begin{tabular}{llllll}
\hline Skor & 0 & 1 & 2 & 3 & 4 \\
\hline Jumlah siswa & 0 & 4 & 24 & 0 & 3 \\
\hline
\end{tabular}

Pada soal tersebut, siswa diminta untuk memeriksa argumen dari dua buah pertanyaan yaitu hubungan antara luas jajargenjang dengan persegi panjang dan sifat diagonal belah ketupat menjadi jajargenjang. Hanya tiga orang yang dapat menjawab poin a dan $b$ sangat baik sedangkan 24 siswa lainnya dapat menjawab satu poin dengan benar.

Untuk indikator kedua yang berkaitan dengan penalaran analogi, diperoleh hasil jawaban siswa dalam bentuk tabel seperti berikut:

Tabel 5. Hasil Jawaban Siswa Pada Indikator Kedua

\begin{tabular}{llllll}
\hline Skor & 0 & 1 & 2 & 3 & 4 \\
\hline Jumlah siswa & 2 & 23 & 4 & 0 & 2 \\
\hline
\end{tabular}

Pada soal tersebut, siswa diminta untuk memberikan pendapat yang logis mengenai keserupaan konsep pada dua pernyataan yaitu persegi dengan luas $\mathrm{p}^{2}$ dan persegi yang memiliki panjang sisi $\sqrt{16} \mathrm{~cm}$. Dua orang siswa dapat menemukan persamaan dan menjelaskan alasannya dengan baik sedangkan 29 siswa lainnya masih mengalami kesulitan 
dalam menemukan persamaan konsepnya dan menguraikan pendapatnya sehingga menjadi logis.

Untuk indikator ketiga yang berkaitan dengan penalaran transduktif, diperoleh hasil jawaban siswa dalam bentuk tabel seperti berikut:

Tabel 6. Hasil Jawaban Siswa Pada Indikator Ketiga

\begin{tabular}{llllll}
\hline Skor & 0 & 1 & 2 & 3 & 4 \\
\hline Jumlah siswa & 1 & 7 & 13 & 0 & 10 \\
\hline
\end{tabular}

Pada soal tersebut, siswa diminta untuk menguji suatu argumen tentang perbandingan luas suatu persegi berdasarkan keliling yang sudah diketahui. Sepuluh siswa dapat menjawab dengan baik dan 13 siswa dapat menjawab dengan sebagian proses penyelesaian yang benar.

Untuk indikator keempat yang berkaitan dengan penalaran deduktif, diperoleh hasil jawaban siswa dalam bentuk tabel seperti berikut:

Tabel 7. Hasil Jawaban Siswa Pada Indikator Keempat

\begin{tabular}{lccccc}
\hline Skor & 0 & 1 & 2 & 3 & 4 \\
\hline Soal ke-4 & & & & & \\
\hline Jumlah siswa & 0 & 1 & 14 & 15 & 1 \\
\hline Soal ke-5 & & & & & \\
\hline Jumlah siswa & 0 & 11 & 9 & 0 & 7 \\
\hline
\end{tabular}

Pada soal tersebut, siswa diminta untuk menghitung luas arsir pada bangun datar segiempat dan luas jajargenjang dengan menggunakan sifat pada jajargenjang. Berdasarkan hasil tabel, siswa dapat menjawab pertanyaan nomor empat dengan lebih baik apabila dibandingkan dengan soal nomor lima.

Untuk indikator kelima yang berkaitan dengan generalisasi, diperoleh hasil jawaban siswa dalam bentuk tabel seperti berikut:

Tabel 8. Hasil Jawaban Siswa Pada Indikator Kelima

\begin{tabular}{llcccc}
\hline Skor & 0 & 1 & 2 & 3 & 4 \\
\hline Jumlah siswa & 0 & 24 & 7 & 0 & 0 \\
\hline
\end{tabular}

Pada soal tersebut, siswa diminta untuk menghitung luas segiempat pada pola tertentu dan membuat suatu rumus untuk menentukan luas seluruh segiempat pada pola ke-n. Sebanyak 24 siswa masih mengalami kesulitan dalam menentukan luas segiempat pada pola yang ditentukan, tujuh siswa dapat menghitung luas segiempat pada pola yang ditentukan namun mengalami kesulitan pada saat pembentukan rumus dari segiempat yang berpola tersebut. 
Untuk indikator keenam yang berkaitan dengan pemecahan masalah tidak rutin, diperoleh hasil jawaban siswa dalam bentuk tabel seperti berikut:

Tabel 9. Hasil Jawaban Siswa Pada Indikator Keenam

\begin{tabular}{lccccc}
\hline Skor & 0 & 1 & 2 & 3 & 4 \\
\hline Soal ke-7 & & & & & 1 \\
\hline Jumlah siswa & 0 & 0 & 29 & 1 & 1 \\
\hline Soal ke-8 & & & & & \\
\hline Jumlah siswa & 0 & 0 & 16 & 10 & 5 \\
\hline
\end{tabular}

Pada soal tersebut, siswa diminta untuk menyelesaikan masalah kontekstual yang berkaitan dengan segitiga dan segiempat dengan perbedaan unsur yang diketahui pada soal nomor delapan lebih banyak dibandingkan dengan soal nomor tujuh. Dari hasil tabel tersebut, siswa dapat menjawab soal nomor delapan lebih baik daripada soal nomor tujuh.

Berdasarkan hasil yang sudah diperoleh tersebut, siswa masih mengalami kesulitan pada soal yang berkaitan dengan indikator analogi, generalisasi dan soal dengan sedikit unsur yang diketahui. Hal tersebut serupa dengan Sumarni (Sumarni \& Sumarmo, 2016), Ario (Ario, 2015) dan Yenni (Yenni \& Aji, 2016) dikarenakan siswa mengalami kesulitan pada saat menentukan unsur yang harus diperlukan, mengubah suatu unsur tertentu menjadi rumus dan menguraikan pendapatnya sehingga menjadi kesimpulan yang logis.

\section{Pembahasan}

Pembahasan harus menjadi interpretasi hasil bukan pengulangan dari analisis data. Dalam pembahasan didukung berdasarkan ahli atau pakar yang dikutip dari artikel pada jurnal yang memiliki tingkat relevansi dan kemutakhiran yang baik. Kemutakhiran dari relevansi artikel pada jurnal yang baik yaitu 5-10 tahun terakhir.

Pembahasan harus menjadi interpretasi hasil bukan pengulangan dari analisis data. Dalam pembahasan didukung berdasarkan ahli atau pakar yang dikutip dari artikel pada jurnal yang memiliki tingkat relevansi dan kemutakhiran yang baik. Kemutakhiran dari relevansi artikel pada jurnal yang baik yaitu 5-10 tahun terakhir.

\section{KESIMPULAN}

Berdasarkan hasil penelitian, kemampuan penalaran matematik siswa pada MTs PPI 38 Padalarang digolongkan dengan kategori cukup. Hal ini dikarenakan adanya beberapa indikator penalaran yang masih perlu ditingkatkan terutama pada indikator penalaran analogi dan generalisasi sebagaimana yang tertera pada tabel yang sudah diuraikan.

\section{DAFTAR PUSTAKA}

Amelia, R. (2015). Pencapaian Kemampuan Penalaran Matematis Siswa SMP dengan Menggunakan Metode Pembelajaran Inkuiri Terbimbing. Jurnal Ilmiah UPT P2M STKIP Siliwangi, 2(1), 98-105. https://doi.org/10.22460/p2m.v2i1p98-105.169

Ario, M. (2015). Penalaran Matematis Dan Mathematical Habits of Mind Penemuan Terbimbing. Jurnal Ilmu Pendidikan Dan Pengajaran, 2(1), 34-46. 
Hendriana, H., Rohaeti, E. E., \& Sumarmo, U. (2017). Hard Skills dan Soft Skills Matematik Siswa. Bandung: Refika Aditama.

Hermawan, A. S., \& Hidayat, W. (2018). Meningkatkan Kemampuan Penalaran Matematik Siswa SMP Melalui Pendekatan Penemuan Terbimbing. JPMI (Jurnal Pembelajaran Matematika Inovatif), 1(1), 7-20.

Hidayat, W. (2017). Adversity Quotient dan Penalaran Kreatif Matematis Siswa SMA dalam Pembelajaran Argument Driven Inquiry pada Materi Turunan Fungsi. KALAMATIKA Jurnal Pendidikan Matematika, 2(1), 15-28.

Hidayat, W., \& Prabawanto, S. (2018, January). Improving students' creative mathematical reasoning ability students through adversity quotient and argument driven inquiry learning. In Journal of Physics: Conference Series (Vol. 948, No. 1, p. 012005). IOP Publishing.

Ruslan, A. S., \& Santoso, B. (2013). Pengaruh Pemberian Soal Open-Ended Terhadap Kemampuan Penalaran Matematis Siswa. Jurnal Kreano, 4(2), 148-150. https://doi.org/https://doi.org/10.15294/kreano.v4i2.3138

Sholihat, N. A. N., Hidayat, W., \& Rohaeti, E. E. (2018). Faktor Kemampuan Penalaran Matematis dan Penghargaan Diri Siswa SMP. JPMI (Jurnal Pembelajaran Matematika Inovatif), 1(1), 1-6.

Sulistiawati, S., Suryadi, D., \& Fatimah, S. (2015). Desain Didaktis Penalaran Matematis untuk Mengatasi Kesulitan Belajar Siswa SMP pada Luas dan Volume Limas. Kreano, $\begin{array}{lllll}\text { Jurnal Matematika } & \text { Kreatif-Inovatif, } & 6(2), & \end{array}$ https://doi.org/10.15294/kreano.v6i2.4833

Sumarmo, U., Hidayat, W., Zukarnaen, R., Hamidah, M., \& Sariningsih, R. (2012). Kemampuan dan Disposisi Berpikir Logis, Kritis, dan Kreatif Matematik (Eksperimen terhadap Siswa SMA Menggunakan Pembelajaran Berbasis Masalah dan Strategi Think-Talk-Write). Jurnal Pengajaran MIPA, 17(1), 17-33.

Sumarni, C., \& Sumarmo, U. (2016). Penalaran Matematik Dan Kemandirian Belajar Siswa. Edusentris, 3(3), 290-299.

Yenni, \& Aji, R. S. (2016). Analisis Kemampuan Penalaran Matematis Siswa SMP Melalui Model Pembelajaran Numbered Heads Together. Jurnal Prima, V(II), 73-81. 
354 Suharto, \& Chotimah, Kemampuan Penalaran Matematik Siswa MTs ... 